\title{
Economical Motivation and Benefits of using Load Shedding in Energy Management Systems
}

\author{
Walid Emar ${ }^{1}$ \\ Electrical Department, Faculty of Engineering \\ Isra University Amman, Jordan
}

\author{
Ghazi Suhail Al-Barami ${ }^{2}$ \\ Department of Engineering Project Management \\ Isra University Amman, Jordan
}

\begin{abstract}
With declining fossil fuel consumption and rising energy demand for renewable energy, the need for integration of these highly predictable sources into the electricity system increases. At the same time, there is a rise in the price of energy, which increases the willingness of consumers to change their breed in order to reduce the costs, or at least to keep them in an acceptable level. One of the options for optimizing energy savings on the consumer side is to use the principle of demand response. This principle enables the consumer, for example, to have the necessary information to optimize the consumption of electricity so as to minimize it when the energy price is high. In view of the constantly changing conditions in the electricity system, the need for optimization is to be implemented automatically, without the necessity of users of the system. This paper main focus is the formulation and optimization of Demand Side Management using the quasi-quadratic problem (MIQP). The result of such optimization is the use of individual devices that take into account the cost of electricity, the working cycle of the installation, the requirements of the user, the systems And limitations and other input information. The method proposed which, after implementation into the individual member - the energy manager - will ensure the optimal utilization of appliances and other Set up by the witches of a clever house.
\end{abstract}

Keywords-Demand side management; load shedding; energy management system; energy consumption

\section{INTRODUCTION}

Today, the world is in a state of panic and fear as a result of the appearance of some global problems on the surface, the most important of these problems is the energy consumption and depletion of available energy resources, and with the adoption of all aspects of life on energy, the whole world began to develop seeking to secure the needs of them, and while some countries began to store some sources of energy in their territory and prevent exporting their stockpiles from these sources, others began to seize the energy stock of other countries or develop themselves in the direction of alternative energy sources or that it has done all of the above [1].

The high energy required by home appliances, air conditioning and lighting make homes one of the most important areas that affect energy consumption. Smart home technology is a good choice for people who care not only about safety and convenience but also about energy. Utilizing IT-based hardware upgrades such as smart meters, smart devices, PMUs at home, the building, electricity distribution network, and transport network, smart homes and buildings have opportunities to take on more responsibilities in the entire power supply network and face shifting from passive customers to active participants [2-5].

Managing consumption may not only have technical and security reasons but also purely economic. Increasing consumption is necessarily accompanied by increased production, which would not be a problem if production costs grew linearly with the amount of consumption. However, with conventional power plants, when the economic output is exceeded, specific consumption and therefore specific costs will start to grow faster than the output power of the power plant increases [5, 7].

Developing countries such as Gulf Cooperation Council countries (GCC) are in a big problem, especially with the need for energy resources to be one of its exports so as not to affect its economy or to violate international agreements, which helped on the speed of access to its energy reserves which causes a problem of depleting the reserve of its energy resources if for example Oman, one of GCC countries, does not find a quick solution to this problem, it will be a big import for the energy sources which are the movement of all aspects of life in Oman [5-9].

According to the 2012 OECD Annual Report, Oman is seeking to diversify electricity production and reduce the current dependence on oil and gas. In 2012, 97.5\% of electricity and $2.5 \%$ of diesel oil was produced in gas facilities. In order to ensure energy savings in the coming decades, "the Commission remains keen to find ways to benefit from renewable sources of energy from Oman, thereby reducing the energy deficit in an economic and efficient way. Following the Renewable Energy Authority (RAECO) launch a pilot project cannot be implemented after the power is familiar with both the main Balhajtin: First, there is no policy framework, or the other, Sultanate Oman supports fossil fuels, making renewable energy more expensive [6,10-11].

The paper will also deal with one of the possible uses of energy management system - relieving the burden of overhead consumption over production. The contributions of the research work can be summarized below [5, 13].

This article offers the idea of reducing energy consumption and saving energy by controlling all costs individually within the home. This depends on the detection of the peak time it takes and reduces the use of the load by stopping unwanted loads with the consumer priority based on an algorithm that plans to use the load by creating many consumer vector plans so that demand never increases. This can be achieved 
individually and among many users of the community or region.

The result of this paper should be an efficient and effective way of managing hardware and home and intelligent buildings through DSM. The paper path should check the DSM optimization and control approach for load management specified in homes and among multiple users of the community or region.

\section{ANALYSIS OF HOUSEHOLD ELECTRICAL APPLIANCES}

\section{A. Electricity Consumption at Homes}

Household consumption growth can be explained by the large-scale use of older inefficient appliances as well as by the increase in the number of electrical appliances. Today, many households have two to three television sets, refrigerators and freezers, and increasingly we have laundry or air conditioners. Also worth mentioning is the growing number of entertaining electronics, without which today one cannot imagine everyday life. In addition, the number of family houses and large apartments is growing (residential area is growing) [12].

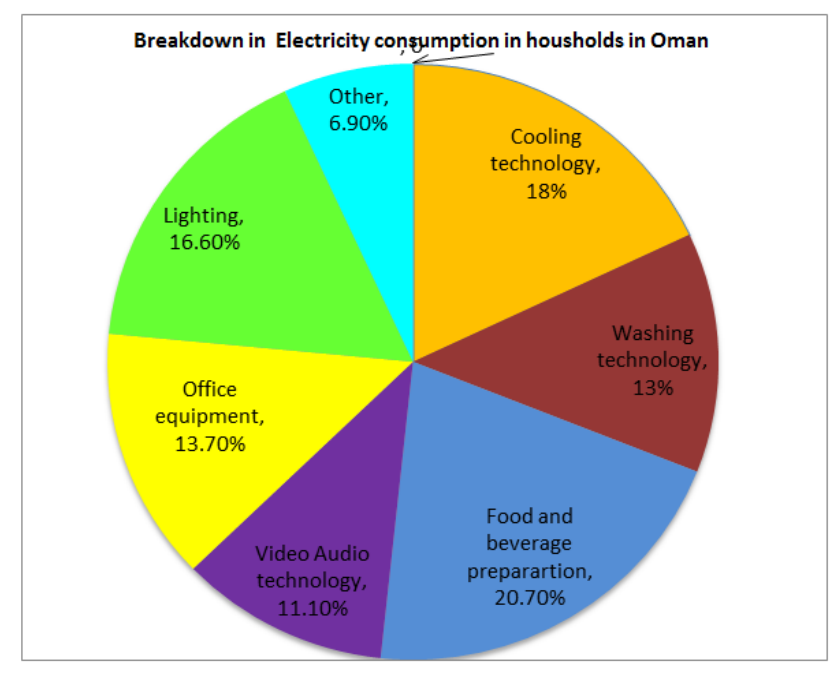

Fig. 1. Breakddown of Electricity Consumption in Households.

TABLE I. DISTRIBUTION OF ELECTRICITY CONSUMPTION IN HOUSEHOLDS - TOTAL

\begin{tabular}{|l|l|l|}
\hline Heating & Water heating & Other electrical appliances \\
\hline $60 \%$ & $20 \%$ & $20 \%$ \\
\hline
\end{tabular}

TABLE II. BREAKDOWN OF ELECTRICITY CONSUMPTION IN HOUSEHOLDS OTHER ELECTRICAL APPLIANCES

\begin{tabular}{|l|l|}
\hline Cooling technology & $18 \%$ \\
\hline Washing technology & $13 \%$ \\
\hline Food and beverage preparation & $20,7 \%$ \\
\hline Video technology & $8,3 \%$ \\
\hline Audio technique & $2,8 \%$ \\
\hline Office equipment & $13,7 \%$ \\
\hline Lighting & $16,6 \%$ \\
\hline Other & $6,9 \%$ \\
\hline
\end{tabular}

Fig. 1 shows an interesting difference between the trend of energy consumption for heating and the consumption of energy for the operation of domestic appliances. In recent years, there has been a significant tightening of standards for the thermal properties of buildings and consequently a corresponding reduction in energy consumption for heating newly built or refurbished houses. However, electricity consumption for normal household operation has increased. According to the average values of the information sources [1], electricity consumption in households is broken down as below.

Every household is of course different. They differ not only in the size and type of living space, the number of people, the equipment of the electrical appliance, but also in their lifestyle. This also corresponds to the range of values as shown in Tables 1 and 2 [14]. The current assumptions relevant directly for the prediction of electricity consumption of small households-households can be summarized in the following points:

- Predictions assume significant energy savings for heating associated with lower energy performance of buildings.

- The forecasts also include the assumption of savings associated with the continuous renewal of electrical appliances, respectively.

- The amount and use of household electrical appliances tends to grow, resulting in increased consumption not only in the other consumption sub-sector but also overall.

Between 2014 and 2040, the prediction, according to the reference scenario, predicts the following savings in electricity consumption [1]:

- Electric heating - a $22 \%$ drop in specific consumption.

- DHW heating by electricity a fall in specific consumption by $18 \%$.

Every household is of course different. They differ not only in the size and type of living space, the number of people, the equipment of the electrical appliance, but also in their lifestyle. This also corresponds to the range of values in the table above.

The prediction of electricity consumption is generated separately for the two main areas of consumption: the manufacturing sphere and the sphere of households. The former is reflected from economic forecasting at macroeconomic level, while the second uses demographic projections, particularly projections of households [15-19].

Therefore, any increase in electricity production induced by increased consumption at a given moment will cause an increase in the price of electricity on the market. From Fig. 2 and 3 it is evident that the increase in the load and therefore the electricity price on the daily market occurs in the morning and in the morning hours before noon and in the evening peak. By managing consumption, we try to limit these peaks by reducing demand and, ultimately, to save production costs $[1$, $11,20]$. 


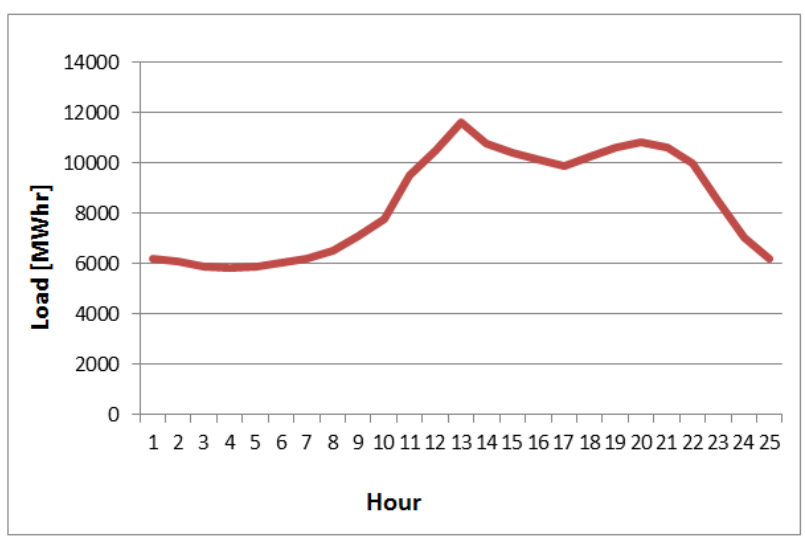

Fig. 2. Example of Power System Load.

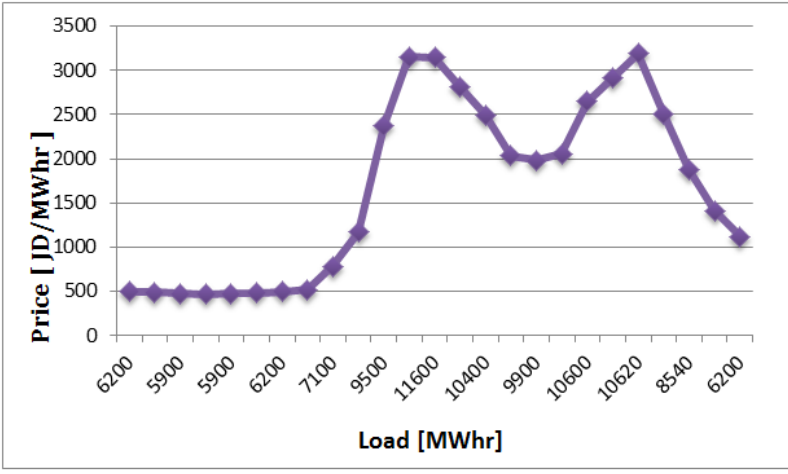

Fig. 3. Example of Electrical Energy Price in the Market.

\section{B. Electricity Production and Consumption in Gulf States}

Most Gulf Cooperation Council (GCC) Member States produce and consume electricity produced within national borders [5]. Production, consumption and maximum load are listed below in Table 3 .

Source: Kingdom of Bahrain Electricity \& Water Authority, Kuwait Ministry of Electricity \& Water, Oman Power and Water Procurement Company, Qatar Electricity \& Water Corporation, Saudi Electricity Company, Electricity \& Cogeneration Regulatory Authority, Abu Dhabi Water and Electricity Company, Dubai Electricity and Water Authority, Sharjah Electricity and Water Authority, Federal Energy and Water Authority, KAPSARC.

The analysis carried out as part of this exploratory study have highlighted a number of interesting trends and have begun to identify energy consumption and saving opportunities that need further investigation and study.

TABLE III. ELECTRICITY PRODUCTION AND CONSUMTION IN GCC COUNTRIES

\begin{tabular}{|l|l|l|l|}
\hline Country & $\begin{array}{l}\text { Production } \\
{[\mathbf{T W h}]}\end{array}$ & $\begin{array}{l}\text { Consumption } \\
{[\mathbf{T W h}]}\end{array}$ & $\begin{array}{l}\text { Peak load } \\
{[\mathbf{G W}]}\end{array}$ \\
\hline Oman & 31.3 & 31.3 & 6.1 \\
\hline Bahrain & 14.1 & 12.6 & 2.9 \\
\hline Kuwait & 68.3 & 60.5 & 12.8 \\
\hline Qatar & 38.7 & 36.1 & 6.7 \\
\hline Saudi Arabia & 304.2 & 274.5 & 56.6 \\
\hline UAE & 116.6 & 121.7 & 20.6 \\
\hline
\end{tabular}

\section{Mathematical Model For the Optimal Solution}

The second area of economic interest where consumption increases are the loss of electricity due to transmission and distribution of electricity to end users. Technical losses that are not caused by human causes can be divided into losses in the lines and losses in voltage transformation. It can be seen from formula (1) that line losses are directly proportional to the quadrant of the maximum current, so the effort to control consumption is therefore to limit the peak of the load during the day, especially morning and evening [18].

$N_{p T}=\frac{3 \rho l}{10^{3} A} I_{m T}^{2} n_{m T}\left(k_{m T}, j, T_{p T}\right)$

where

$\mathrm{N}_{\mathrm{pT}}$ : the costs of losses in the power lines in T-year [USD]

$\rho$ : electrical resistivity of the line $\left[\Omega . \mathrm{mm} 2 . \mathrm{m}^{-1}\right]$

$l$ : power line length $[\mathrm{m}]$

A: wire cross section $\left[\mathrm{mm}^{2}\right]$

$\mathrm{I}_{\mathrm{mT}}$ : maximum load of the line in the T-th year [A]

$\mathrm{n}_{\mathrm{mT}}$ : Marginal Costs to Measure losses in the line in the TYear [USD / kW]

$\mathrm{k}_{\mathrm{mT}}$ : the coefficient of the maximum loss in the T-year

$\mathrm{j}$ : voltage line level

$\mathrm{T}_{\mathrm{pT}}$ : period of total losses in the T-th year [h]

A similar case occurs due to losses as a result of voltage transformation. Here, the losses are dependent on the transformer's maximum load quadrant as seen from the transformer losses calculation formula (2) [17].

$N_{t r T}=P_{o}\left(n_{p j}+T_{p r} n_{w j}\right)+P_{k n} \frac{s_{m T}^{2}}{S_{n}^{2}}\left(n_{p j}+T_{z} n_{w j}\right)$

Where

$\mathrm{N}_{\mathrm{trT}}$ : the cost of losses in the transformer in the T-th year

$\mathrm{P}_{0}$ : rated transformer losses at open circuit.

$\mathrm{P}_{\mathrm{kn}}$ : rated transformer losses at open circuit.

$\mathrm{n}_{\mathrm{pj}}$ :Steady state component of long-term marginal costs including power losses up to the $\mathrm{j}$-th voltage level [USD / kW].

$\mathrm{n}_{\mathrm{wj}}$ : Variable component of long-term marginal costs including work losses up to the

j-th voltage level [USD / $\mathrm{kWh}$ ].

$\mathrm{S}_{\mathrm{mT}}$ : annual maximum transformer load in T-th year [MVA].

$\mathrm{S}_{\mathrm{n}}$ : Transformer rated power [MVA].

$\mathrm{T}_{\mathrm{pr}}$ : Annual transformer operation time [h]

$\mathrm{T}_{\mathrm{z}}$ : Annual transformer losses [h]

An integral part of the operation of both transmission and distribution systems is the development and expansion of the power system network to meet customer needs. The big issue 
is the design of the power lines so that it can transfer power at the time of the peak load and, on the other hand, that the design of this line cost is not over-sized above economic efficiency.

The mathematical model for optimal solution is given as explained in $[1,11]$ as follows:

$$
\begin{gathered}
\sum_{i=2}^{24}\left(P_{2 i}-P_{2 i-1}\right)^{2}=\text { Min } \\
P_{2 i}=P_{1 i}-\Delta P_{i} \\
\left|P_{2 i}-P_{1 i}\right| \leq\left|\Delta P_{m i}\right| \\
\sum_{i=1}^{24} \Delta P_{i}=0
\end{gathered}
$$

Where

$\mathrm{P}_{1 \mathrm{i}}$ : the power of the original load at hour $\mathrm{i}[\mathrm{MW}]$

$\mathrm{P}_{2 \mathrm{i}}$ : the power of the balanced load at hour i [MW]

$\mathrm{P}_{\mathrm{mi}}$ : Limits of power change in hour $\mathrm{i}[\mathrm{MW}]$

$\Delta \mathrm{P}_{\mathrm{i}}$ : change of power in hour $\mathrm{i}[\mathrm{MW}]$

i: day hour

\section{ECONOMIC BENEFITS OF MANAGING THE CONSUMPTION OF SMALL CUSTOMERS}

From the previous considerations and studies, we have come to the conclusion that the most suitable sector for consumption management in Oman as a study case of this paper is the low level consumption of households through indirect control of appliances, which can change the time of operation without greatly reducing the comfort of using this appliance. For the initial analysis, a smaller area in Oman having 115 households with a total annual consumption of 345 MWh has been chosen. As input data, the average diagrams (2015-2017) for individual seasons - spring (March-May), summer (June-August), autumn (September-November) and winter (December-February) have been chosen [1, 13].

In order to keep a complete comfort of the customers, we had to manage only the appliances that would not limit the customers. In this case, the thermal storage devices just like water heaters that are currently mostly controlled by BRC global standards and can be used to reduce the load in an emergency are the most suitable. The opposite direction of cooling has the same inertia effect.

\begin{tabular}{|c|c|c|c|c|c|c|c|c|c|}
\hline & \multicolumn{2}{|l|}{ Spring } & \multicolumn{2}{|l|}{ Summer } & \multicolumn{2}{|l|}{ Autumn } & \multicolumn{2}{|l|}{ Winter } \\
\hline & & $\begin{array}{l}\text { Working } \\
\text { day }\end{array}$ & Weekend & $\begin{array}{l}\text { Working } \\
\text { day }\end{array}$ & Weekend & $\begin{array}{l}\text { Working } \\
\text { day }\end{array}$ & Weekend & $\begin{array}{l}\text { Working } \\
\text { day }\end{array}$ & Weekend \\
\hline \multicolumn{2}{|c|}{$\begin{array}{l}\text { average daily consumption } \\
\text { of the area }[\mathbf{k W h}]\end{array}$} & 2166,3 & 2270,5 & 1690,6 & 1694,7 & 2122,7 & 2202,0 & 2644,9 & 2761,5 \\
\hline \multirow{2}{*}{$\begin{array}{l}\text { maximum daily } \\
\text { potential } \\
\text { shedding }\end{array}$} & {$[\mathbf{k W h}]$} & 84,6 & 170,7 & 84,6 & 170,7 & 84,6 & 170,7 & 84,6 & 170,7 \\
\hline & $\%$ & 3,91 & 7,52 & 5,00 & 10,07 & 3,99 & 7,75 & 3,20 & 6,18 \\
\hline \multirow{2}{*}{$\begin{array}{l}\text { used daily } \\
\text { potential } \\
\text { shedding }\end{array}$} & {$[\mathbf{k W h}]$} & 52,6 & 81,7 & 44,7 & 44,4 & 64,8 & 110,3 & 55,3 & 104 \\
\hline & $\%$ & 2,43 & 3,60 & 2,64 & 2,62 & 3,05 & 5,01 & 2,09 & 3,77 \\
\hline \multicolumn{2}{|l|}{ Days no. } & 66 & 26 & 66 & 26 & 65 & 26 & 64 & 27 \\
\hline \multicolumn{2}{|c|}{$\begin{array}{l}\text { Original cost of energy } \\
\text { per day }\end{array}$} & & & & & & & & \\
\hline \multicolumn{2}{|c|}{$\begin{array}{l}\text { The difference in energy } \\
\text { costs per day }\end{array}$} & 7,26 & 7,54 & 8,03 & 9,02 & 22,06 & 33,15 & 22,06 & 42,29 \\
\hline \multicolumn{2}{|c|}{$\begin{array}{l}\text { The difference in energy } \\
\text { costs for the whole period } \\
\text { [USD] }\end{array}$} & 479 & 196 & 530 & 235 & 1434 & 862 & 1412 & 1142 \\
\hline \multicolumn{2}{|c|}{$\begin{array}{l}\text { Total difference per year } \\
\text { [USD] }\end{array}$} & 6289 & & & & & & & \\
\hline
\end{tabular}

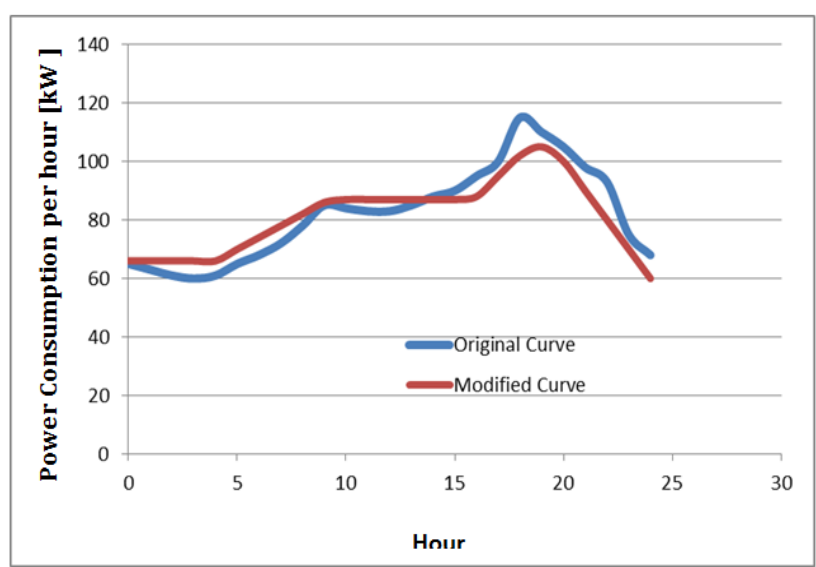

Fig. 4. Load Duration Curve Modification in One Day in Autumn.

TABLE IV. Estimation of Cost SAVINGS OF ENERgy Purchase During CONTROL 
The BRC global standards for both small consumers (households), where switched appliances are predominantly storage stoves for heating and hot water boilers, and large consumers (enterprises) that control non-industrial appliances such as water pumps, air conditioning and heating.

Fig. 4 shows an example of load shedding on a working day in the autumn, where the positive control values represent a delay in consumption (turning off the appliances) and the negative value represents the switching on of the appliances. We have determined the shedding values so as to limit the power consumption as much as possible and to balance the load diagram as much as possible.

The main objective was therefore to shift the consumption from midday (weekends) and afternoon peak to morning hours when the load is the smallest. From the calculation of the maximum load shedding potential in the given area, $84.6 \mathrm{kWh}$ could be shed during the working day and $170.7 \mathrm{kWh}$ during the weekend, which represents from 3 to $10 \%$ of the daily energy consumption (Table 4). When calculating the difference in the cost of purchasing electricity at average prices on the daily market, I saved 6,289 USD per year.

\section{Simulation Results}

Economical benefits of Demand Side Management are obtained through adopting soft options like higher prices during peak hours, low rates during off-peaks, interruptible tariffs which improve the efficiency of various end-users through developing and promoting energy efficient technologies. An example is the use of energy storage units to store energy during off-peak hours and discharge them during peak hours DSM, also includes options such as renewable energy systems, independent power purchase, etc. thus to meet the customer's demand at the lowest possible cost.

When setting control limits, it is assumed that all devices will be connected to the information network and will be able to drive according to the system's instructions. In the real situation, these limits will be reduced by parts of appliances that will not be in the system.

It is also assumed that all customers will proceed to control their appliances. A further reduction in potential will be due to the unwillingness of customers to engage in the management system.

This unwillingness is mainly due to an interference with the daytime activities of a person, thereby losing a certain amount of freedom and comfort, and moving the function of relatively noisy appliances (dishwasher, washing machine) into the early morning hours (3-6 hours).

In such a small area of management, it encounters a problem of very small values, where these control values correspond only to the power of several units of appliances, so such average values will in most cases be different from the real situation.

The larger the area will be taken into account and the greater the number of appliances will be involved in the management, the average estimates will be closer to the actual values, so it is advisable to count with the whole territory of Amman.

\section{CONCLUSION}

The energy demand manager DSM, described in this work, is subject to the following goals:

Encourage consumers to use less energy during peak hours, or to transfer the time of energy utilization to valley hours, such as night and weekends.

Reduce the need for investments in networks and/or power generation plants to meet the peak needs. Demand management does not necessarily lead to a reduction in total energy consumption.

One of the main objectives of demand management is the burden of consumers on the basis of the real price of the facilities and services they receive. If it is possible to charge consumers amounts to lower electric power during peak hours, and more during peak hours, supply and demand will encourage consumers to theoretically use less electricity during peak hours, which is achieved Main objective of demand management.

The problem of small values does not occur with such a large sample of households, with the participation of only $20 \%$ of them. The average values in this case are very credibly close to the real values.

By estimating the potential of indirect management, it can be said that consumers have a greater value of free use of their appliances at their liking than the price advantage of electricity for these appliances.

The maximum indirect control potential ranges from 6 to $20 \%$ of the daily MOO energy consumed, depending on the day of the week and the season. The usable potential is only between 3 and $8 \%$ and only about $1 \%$ to $2 \%$ for $20 \%$ of households.

As a result of indirect management, losses due to MOO are reduced by $3 \%$ at full potential and by $1 \%$ in $20 \%$ of households.

If the electricity for indirect management was purchased on the daily market, it would save several million crowns annually, but after including the price advantage, this procedure would be very wasteful.

As a result of the alignment of the subscription diagram, the use of the line would increase and increase safety due to the lower peaks in the take-off but would not save on the payments for the reserved capacity of the transmission system.

In spite of all these positive issues, it should be realized that for this management a massive infrastructure connected to each household and processing huge volume of data would have to be built. According to estimates, the net present value of expenditures could reach up to USD 4.2 billion by 2040 [17]. 


\section{REFERENCES}

[1] Jakub Martínek, Potential of Load-shedding system in distribution network PRE, Faculty of Electrical Engineering, Department of Economics, Management and Humanities, Czech technical university in Prague, Prague 2017.

[2] Palensky, P., Dietrich, D., "Demand side management: Demand response, intelligent energy systems, and smart loads", Industrial Informatics, IEEE Transactions, 2011, Vol. 7, No. 3, 381-388.

[3] Michael H. Smith, Karlson 'Charlie' Hargroves and Cheryl Desha Peter Stasinopoulos, "Whole system design an integrated approach to sustainable engineering". London: Earthscan, 2009.

[4] Al Hatmi, Y., \& Tan, C. S., "Issues and Challenges With Renewable Energy in Oman", Gas (BCM), 2013, Vol. 4, No. 9, 212-218.

[5] Pauceanu, A.M., "Strategic Energy Management in Oman Speech, Arab Renewable Energy Commission", Energy Economy \& Energy Management Forum for MENA, May, Amman, Jordan, 1-4, 2015.

[6] Darwish, M. A., "Energy status in Qatar", International Journal of Energy Sector Management, 2013, Vol. 7, No. 2, 163 - 193.

[7] Balitskiy, S., Bilan, Y., Strielkowski, W., Štreimikienė, D. , "Energy efficiency and natural gas consumption in the context of economic development in the European Union", Renewable and Sustainable Energy Reviews, 2016, No. 55, 156-168. DOI: http://dx.doi.org/10.1016/j.rser.2015.10.053.

[8] Kasperowicz, R (2015), "Economic growth and CO2 emissions: the ECM analysis", Journal of International Studies, Vol. 8, No. 3, 2015, 91 98. DOI: 10.14254/2071-8330.2015/8-3/7.

[9] Al - Gharibi, H. 2014. Urban Growth from patchwork to sustainability, Case study: Muscat. [Online]. Available: http://www.opus4.kobv.de 2014.

[10] Solarin, S. A. and Shahbaz, M. 2013. Trivariate causality between economic growth, urbanisation and electricity consumption in Angola: Cointegration and causality analysis. MPRA Paper No. 45580. Retrieved from http://www.mpra.ub.uni-muenchen.de/45580/.

[11] M. Z. Huq and S. Islam, "Home area network technology assessment for demand response in smart grid environment," in Universities Power
Engineering Conference (AUPEC), 2010 20th Australasian, 2010, pp. 16.

[12] A. Arabali, M. Ghofrani, M. Etezadi-Amoli, M. Fadali, and Y. Baghzouz, "Genetic-algorithm-based optimization approach for energy management," Power Delivery, IEEE Transactions on, vol. 28, pp. 162170, 2013.

[13] Matti Palonen, Ala Hasan, and Kai Siren, "A Genatic Algorithm for Optimization of Building Envelope and HVAC system Parameters," in Eleventh International IBPSA Conference, Glasgow, Scotland, 2009, pp. 159-166.

[14] Oman PAEW (Oman Public Authority for Electricity and Water). 2015a. "Annual Report." 2015b. "Comprehensive National Energy Strategy."

[15] K. Aduda, W. Zeiler, and G. Boxem, "Smart Grid-BEMS: The Art of Optimizing the Connection between Comfort Demand and Energy Supply," in Intelligent Systems Design and Engineering Applications, 2013 Fourth International Conference on, 2013, pp. 565-569.

[16] M. Roscia, M. Longo, and G. C. Lazaroiu, "Smart City by multi-agent systems," in Renewable Energy Research and Applications (ICRERA), 2013 International Conference on, 2013, pp. 371-376.

[17] F. I. Vázquez, W. Kastner, S. C. Gaceo, and C. Reinisch, "Electricity load management in smart home control," in 12th Conference of International Building Performance Simulation Association, 2011, pp. 957-964.

[18] M. A. A. Pedrasa, T. D. Spooner, and I. F. MacGill, "Coordinated scheduling of residential distributed energy resources to optimize smart home energy services," Smart Grid, IEEE Transactions on, vol. 1, pp. 134-143, 2010.

[19] P. Zhao, S. Suryanarayanan, and M. G. Simões, "An energy management system for building structures using a multi-agent decision-making control methodology," Industry Applications, IEEE Transactions on, vol. 49, pp. 322-330, 2013.

[20] L. Hurtado, P. Nguyen, and W. Kling, "Agent-based control for building energy management in the smart grid framework," in Innovative Smart Grid Technologies Conference Europe (ISGT-Europe), 2014 IEEE PES, 2014, pp. 1-6. 